\title{
Hak Mogok Kerja dalam Perspektif Yuridis dan Sosiologis
}

\author{
Willy Farianto \\ Peserta Program Doktor Ilmu Hukum UNDIP \\ Jl. Professor Haji Soedharto SH, Kampus Undip Tembalang \\ Jawa Tengah 50271 \\ willy.farianto@fardalaw.com
}

\begin{abstract}
Issues raised in this paper are: First, how do we know whether the strike conducted by the employers is a legal one? Second, how do we protect employers from some invalid strike actions? This research is a normative juridical (legal normative research). The approach used in this study is legislative approach (statute approach) and the conceptual approach. The study concluded, first, that employers' strikes will belong to legal ones if: a) a deliberation about the specifics of disputes between the unions and employers has been truly held; $b$ ) the request of negotiation has been truly rejected by the owners; $c$ ) they has been failed in two times within a period of two (2) weeks to invite other parties to negotiate. Second, the employer could do either the refusal to the implementation of a strike in the framework of the three stages; before, during and after the strike; or did lock out done by the owners.
\end{abstract}

Keyword: Strike, employers, owners

\begin{abstract}
Abstrak
Permasalahan yang diangkat dalam penelitian ini adalah: Pertama, bagaimana mengetahui mogok kerja yang dilakukan pekerja adalah mogok kerja yang sah? Kedua, bagaimanakah melindungi pengusaha dari aksi mogok kerja yang tidak sah? Penelitian ini adalah penelitian yuridis normatif (normatif legal research). Pendekatan penelitian yang digunakan ialah pendekatan perundang-undangan (statute approach), dan pendekatan konseptual (conceptual approach). Hasil penelitian menyimpulkan, pertama, mogok kerja yang dilakukan pekerja adalah mogok kerja yang sah apabila: a) benar-benar sudah diadakan perundingan yang mendalam mengenai pokok-pokok perselisihan antara serikat pekerja dengan majikan; b) benar-benar permintaan untuk berunding telah ditolak oleh pihak pengusaha; c) telah dua kali dalam jangka waktu 2 (dua) minggu tidak berhasil mengajak pihak lain untuk berunding. Kedua, pengusaha dapat melakukan perlawanan terhadap pelaksanaan mogok kerja dalam kerangka tiga tahapan, sebelum, selama dan sesudah mogok kerja berlangsung; ataupun melakukan lock out atau penutupan perusahaan oleh pengusaha.
\end{abstract}

Kata Kunci: Mogok kerja, pekerja, pengusaha 


\section{Pendahuluan}

Mogok kerja adalah tindakan pekerja secara bersama-sama menghentikan atau memperlambat pekerjaan sebagai akibat gagalnya perundingan atas tututan atau pelaksanaan hak normatif. Pada prinsipnya, mogok kerja hanya dapat dilakukan dan dilaksanakan di satu perusahaan, namun dapat pula dilakukan di beberapa perusahaan dalam satu kelompok perusahaan. Sementara itu, pekerja dan/atau serikat pekerja dapat mengajukan wakilnya dalam jumlah terbatas kepada instansi atau organisasi atau lembaga untuk dapat melakukan penyelesaian masalah dalam kerangka perselisihan hubungan industrial yang sedang dihadapi. Pemogokan total atau sebagian berakibat pada penurunan atau bahkan penghentian produktivitas. Serikat pekerja/buruh yang bijaksana akan berpikir jauh tentang rencana dilaksanakannya pemogokan. ${ }^{1}$

Bilamana diperhatikan kedudukan pekerja dalam sebuah hubungan industrial memegang peranan pokok, yakni bahwa ketiadaan unsur pekerja dalam sebuah proses produksi, akan mengakibatkan proses produksi tersebut tidak akan berjalan dengan baik dan lancar serta mencapai tujuannya. Akan tetapi, adanya keadaan saling membutuhkan antara pengusaha dan pekerja ini tidak dapat berjalan harmonis dikarenakan ada ketidakharmonisan ketika masing-masing pihak saling berhadapan. Masing-masing pihak saling merasa memberikan kontribusi paling besar atas keberhasilan atau berjalannya sebuah perusahaan. Adapun pada sisi pekerja, dalam mengungkapkan sebuah ketidakpuasan tentang situasi dan kondisi di perusahaan, dapat menggunakan mekanisme mogok kerja. Sedangkan pada sisi yang lain, pengusaha dapat menggunakan mekanisme lock out atau penutupan perusahaan.

Para pekerja memperoleh hak untuk mogok kerja karena hak ini diakui sebagai hak dasar pekerja dan diatur dalam perundang-undangan, namun mogok kerja tidak dapat dilakukan secara bebas karena ada batasan dan ketentuan yang mengaturnya. Pemogokan sangat merugikan pihak-pihak dalam hubungan industrial. Pemogokan didefinisikan sebagai tindakan yang dilakukan oleh pekerja terhadap pengusaha dengan tujuan menekan pengusaha atau perusahaan

${ }^{1}$ Asri Wijayanti, Hukum Ketenagakerjaan Pasca Reformasi, Sinar Grafika, Jakarta, 2010, hlm. 98. 
untuk memenuhi tuntutannya atau sebagai tindakan solidaritas untuk teman sekerja lainnya. ${ }^{2}$

Mogok kerja diakui sebagai salah satu hak dasar pekerja/buruh secara universal, yakni wujud dari hak atas kebebasan berserikat dan perlindungan atas hak berorganisasi. Pada tataran global, mogok sebagai hak (strike as right) tercermin pada Pasal 23 ayat (4) Universal Decralation of Human Rights, yang menjamin hak setiap orang untuk membentuk dan menjadi anggota serikat buruh guna melindungi kepentingannya. Selanjutnya, Pasal 8 ayat (1d) United Nations International Convenant on Economic, Social, and Cultural Right Tahun 1966 menjamin hak mogok secara eksplisit. Sejalan dengan ketentuan-ketentuan hukum internasional tersebut, Konvensi ILO No. 87 Tahun 1948 tentang "Freedom of Assosiation and Protection of the Right to Organize" dan Konvensi ILO No. 98 Tahun 1949 tentang "Aplications of the Principles of the Right to Organize and to Bargain Collectively", secara implisit mengakui hak mogok. Lebih jauh dapat dikatakan bahwa Konvensi ILO No. 87 dan 98, merupakan landasan bagi hak-hak yang fundamental, dimana masyarakat yang bebas menyukainya. Oleh karena itu, Komite "ILO Freedom of Association" berpendapat bahwa hak mogok tidak hanya merupakan sarana yang sah, melainkan juga merupakan sarana yang esensial yang dimiliki kaum buruh untuk meningkatkan dan mempertahankan kepentingan sosial ekonominya. ${ }^{3}$ Konvensi ILO Nomor 87 Tahun 1948 tentang Kebebasan Berserikat dan Perlindungan Hak untuk Berorganisasi dan Konvensi ILO Nomor 98 Tahun 1949 tentang Pelaksanaan Prinsip-Prinsip Hak Berorganisasi dan Berunding Bersama secara tersirat mengakui hak mogok, sehingga kedua Konvensi tersebut merupakan landasan yang universal atas hak serikat pekerja untuk mogok.

Selanjutnya, Konvensi ILO No. 154 Tahun 1981 tentang Promotion of Collective Bargaining memperluas pengertian collective bargaining dengan memasukkan semua perundingan bersama antara pengusaha atau beberapa pengusaha atau gabungan beberapa organisasi pengusaha dengan satu atau

${ }^{2}$ Abdul Khakim, Dasar-Dasar Hukum Ketenagakerjaan Indonesia, Citra Aditya Bakti, Jakarta, 2009, hlm. 172.

${ }^{3}$ Aloysius Uwiyono, Hak Mogok di Indonesia, Program Pascasarjana Universitas Indonesia, Jakarta, 2001, hlm. $15-16$. 
beberapa organisasi buruh untuk menentukan kondisi kerja dan syarat-syarat kerja, atau mengatur hubungan antara buruh atau serikat buruh dengan pengusaha. ${ }^{4}$ Hak mogok yang tidak dapat dipisahkan dari hak berunding kolektif dalam Konvensi ini diperluas tidak hanya terbatas pada masalah perundingan perjanjian perburuhan saja, melainkan juga perundingan tentang syarat-syarat kerja dan kondisi kerja di luar perjanjian perburuhan, bahkan juga menyangkut hubungan antara pengusaha atau organisasi pengusaha dengan satu atau beberapa serikat buruh. Perluasan ruang lingkup hak mogok ini sejalan dengan apa yang diatur dalam European Social Charter.

Mogok kerja atau unjuk rasa sebenarnya hanya salah satu upaya untuk memperjuangkan hak-hak pekerja. Sejak era reformasi kasus pemogokan marak di mana-mana, bahkan seperti menjadi mode. Di satu sisi, sebenarnya hal ini menunjukkan adanya ketidakpuasan di kalangan pekerja, karena para pekerja semakin mengetahui hak dan kewajibannya, namun di sisi lain mencerminkan adanya keprihatinan, karena masih adanya mogok kerja yang dilakukan secara asal-asalan, yaitu bukan diakibatkan gagalnya perundingan antara pekerja dan pengusaha. Di samping itu, aksi mogok kerja ini ada yang disertai dengan tindakan destruktif berupa pengrusakan fasiltas perusahaan, fasilitas umum, dan mengganggu kepentingan umum. Padahal, dalam Undang-Undang No. 13 Tahun 2003 mengatur bahwa mogok kerja hanya dapat dibenarkan bila dilakukan secara sah, tertib, damai, dan sebagai akibat gagalnya perundingan. ${ }^{5}$

Pengaturan mengenai mogok kerja diatur khusus pada Pasal 137 sampai Pasal 145 dalam Undang-Undang No. 13 Tahun 2003 tentang Ketenagakerjaan. Peraturan pelaksanaan mogok kerja diatur oleh Kepmenakertrans No. 232/MEN/2003 tentang Akibat Hukum Mogok Kerja Yang Tidak Sah. Peraturan perundang-undangan yang mengatur mengenai mogok kerja masih menemui banyak tantangan, oleh sebab kelemahan yang muncul yang membuat mogok kerja menjadi sesuatu kegiatan yang dapat disalahgunakan oleh pihak-pihak yang tidak bertanggung jawab. Pihak tertentu yang dapat menggunakan kegiatan mogok kerja, yang semestinya diinisiasi untuk kepentingan gagalnya

\footnotetext{
${ }^{4}$ Ibid., hlm. 61.

${ }^{5}$ Adrian Sutedi, Hukum Perburuban, Sinar Grafika, Jakarta, 2009, hlm. 82 - 83.
} 
perundingan perselisihan hubungan industrial, menjadi bertujuan untuk kepentingan pribadi dan bukan untuk memperjuangkan kepentingan bersama. ILO juga beranggapan bahwa mogok (strike) muncul dalam beberapa jenis, baik untuk menduduki tempat kerja, mogok dengan cara memperlambat kerja atau bekerja untuk menguasai, dimana tidak hanya untuk sekedar upaya menghentikan pekerjaan, dapat dilakukan dengan damai, dan diakui oleh Komisi Kebebasan Berserikat. Catatannya adalah bahwa pelaksanaan hak mogok dilakukan secara damai, sebagaimana Komisi tersebut menetapkan bahwa: Apabila hak mogok dijamin oleh undang-undang nasional, maka pertanyaan yang sering muncul adalah apakah tindakan yang dilakukan oleh para pekerja tersebut merupakan aksi mogok yang berdasarkan undang-undang. Penghentian kerja apapun, secara singkat dan terbatas, biasanya dapat dianggap sebagai aksi mogok. Adalah lebih sulit untuk menentukan bila tidak ada penghentian pekerjaan seperti ini namun memperlambat pekerjaan (mogok lambat) atau bila peraturan kerja diterapkan terhadap surat (kerja untuk menguasai keadaan); maka bentuk-bentuk aksi mogok ini sering sama hebatnya dengan penghentian kerja secara total. Dikarenakan kebiasaan dan undang-undang nasional sangat bervariasi dalam hal ini, maka Komisi berpendapat bahwa pembatasan bentuk aksi mogok hanya dapat dibenarkan bila tindakan tersebut berhenti secara damai. Komisi berpendapat bahwa pembatasan terhadap tindak pencegahan kerja sewaktu mogok dan pendudukan tempat kerja harus dibatasi pada kasus-kasus di mana tindakan tersebut berhenti secara damai. ${ }^{6}$

Mogok kerja sendiri oleh Budiono, dapat dibedakan menjadi dua macam tuntutan, yakni tuntutan normatif dan tuntutan tidak normatif. Tuntutan normatif, yaitu tuntutan yang didasarkan pada ketentuan-ketentuan yang terdapat dalam peraturan perundang-undangan (termasuk yang diatur di dalam perjanjian kerja, peraturan perusahaan atau perjanjian kerja bersama). Sedangkan tuntutan tidak normatif, adalah tuntutan yang tidak didasarkan pada peraturan perundang-undangan. ${ }^{7}$

\footnotetext{
${ }^{6}$ ILO, Hak Mogok, ILO,Jakarta, 2012, hlm. 12.

${ }^{7}$ Adrian Sutedi, Op.Cit., hlm. 176-177.
} 
Fenomena mogok kerja yang terjadi saat ini sudah keluar dari batas yang diatur oleh peraturan perundang-undangan. Mogok kerja saat ini sangat mudah dilakukan ketika tuntutan atau keinginan serikat pekerja atau pekerja tidak dipenuhi oleh pengusaha. Beberapa kasus mogok kerja yang tidak sesuai peraturan perundang-undangan yang penulis tangani, contohnya di Perusahaan Keramik di Karawang, serikat pekerja memberitahukan rencana mogok kerja kepada pengusaha dengan alasan solidaritas terhadap karyawan di perusahaan lain yang sedang melakukan mogok kerja. Perusahaan perkebunan di Jakarta, Federasi Serikat Pekerja memberitahukan rencana mogok kerja dengan alasan besaran bonus tahunan kurang. Perusahaan makanan di Karawang melakukan mogok kerja karena beberapa pengurus serikat pekerjanya terkena pemutusan hubungan kerja yang disebabkan perusahaan melakukan efisiensi. Fenomena paling sering dilihat oleh masyarakat adalah mogok kerja yang terjadi hampir setiap tahun di setiap provinsi, untuk melakukan tuntutan kenaikan upah minimum provinsi atau kabupaten.

Melihat fenomena yang terjadi sekarang ini, menjadi sulit untuk membedakan aksi pekerja sebagai mogok kerja atau demonstrasi, ketika aksi dilakukan bukan karena gagal perundingan, hak yang dituntut bukan hak normatif dan pemberitahuan aksi pekerja di tujukan kepada Kepolisian bukan kepada Instansi yang bertanggungjawab di bidang ketenagakerjaan dan perusahaan.

Judul di atas diajukan sebagai bentuk upaya mengkaji kembali tentang esensi mogok kerja sebagai hak dasar pekerja/buruh. Mengapa demikian? Hal ini dikarenakan, mogok kerja sebagai hak, dewasa ini berkembang tidak melulu diakibatkan semata-mata akibat gagalnya perundingan, akan tetapi menjadi satu metode untuk menggagas peluang penetrasi positif-negatif terhadap kebijakan perusahaan (atau pengusaha). Mogok kerja, oleh pekerja, digunakan sebagai cara sekaligus sebagai hak yang dilaksanakan untuk menggalang kekuatan untuk mendapatkan posisi sebanding dengan pengusaha. Dengan demikian, pelaksanaan hak seakan-akan menjadi cara yang paling efektif ketika pekerja berbeda pendapat dengan pengusaha dalam pelaksanaan suatu hubungan kerja. 


\section{Rumusan Masalah}

Berdasarkan uraian latar belakang mogok kerja tersebut di atas, maka permasalahan yang diangkat dalam tulisan ini adalah: Pertama, bagaimana mengetahui mogok kerja yang dilakukan pekerja adalah mogok kerja yang sah? Kedua, bagaimanakah melindungi pengusaha dari aksi mogok kerja yang tidak sah?

\section{Tujuan Masalah}

Adapun tujuan dari penelitian ini adalah untuk: Pertama, memahami prosedur dan tata cara pelaksanaan mogok kerja di Indonesia agar dapat dilaksanakan secara sah; Kedua, untuk melindungi pengusaha dari kegiatan mogok kerja yang tidak sah.

\section{Metode Penelitian}

Penelitian ini adalah penelitian yuridis normatif (normatif legal research). Pendekatan penelitian yang digunakan oleh peneliti ialah pendekatan perundang-undangan (statute approach), dan pendekatan konseptual (conceptual approach). Pendekatan perundang-undangan digunakan oleh peneliti dengan maksud untuk mencari dasar hukum dan kandungan filosofis suatu perundangundangan, serta untuk mempelajari adakah konsistensi dan kesesuaian ketentuan-ketentuan yang ada dalam suatu undang-undang atau antara suatu undang-undang dengan undang-undang lainnya, yang dalam penelitian ini peraturan perundang-undangan yang terkait dengan mogok kerja.

Dalam penelitian ini, jenis penelitian yang digunakan penelitian yuridisnormatif, adalah suatu prosedur ilmiah untuk menemukan kebenaran berdasarkan logika keilmuan dari sisi normatifnya yang objeknya adalah hukum itu sendiri, yang difokuskan untuk mengiventarisasi dan mengkaji kaidah-kaidah atau norma-norma dalam hukum positif. ${ }^{8}$

\footnotetext{
${ }^{8}$ Johnny Ibrahim, Teori dan Metode Penelitian Hukum Normatif, Bayumedia, Malang, 2011, hlm. 57.
} 
Bahan hukum yang digunakan dalam penulisan ini adalah bahan hukum primer yang berupa peraturan perundang-undangan, bahan hukum sekunder yang terdiri dari buku teks, jurnal hukum, kamus hukum, hasil penelitian hukum, serta dokumen penunjang lainnya dan bahan hukum tersier khususnya yang berkaitan dengan permasalahan mogok kerja di Indonesia.

\section{Hasil Penelitian dan Pembahasan}

\section{Sebab Terjadinya Mogok Kerja}

Mogok kerja dapat timbul oleh karena berbagai alasan yang mendasarinya. Pengakuan mogok kerja sebagai hak pekerja/serikat pekerja, dibarengi dengan asumsi bahwa alasan dilakukannya mogok kerja harus dapat diterima dan sesuai dengan ketentuan yang berlaku di negara tertentu. ILO juga menyadari bahwa mogok kerja dilaksanakan atas dasar permintaan tertentu oleh pekerja kepada pengusaha. Sifat permintaan yang diajukan melalui aksi mogok dapat digolongkan sebagai hal yang terkait dengan pekerjaan (berusaha menjamin atau memperbaiki kondisi kerja atau kehidupan para pekerja), serikat buruh (berusaha menjamin atau mengembangkan hak-hak organisasi serikat buruh dan para pemimpin mereka), atau yang terkait dengan politik. Kedua kategori yang disebutkan pertama tersebut tidak menimbulkan masalah khusus apapun karena dari awalnya Komisi Kebebasan Berserikat telah membuat keputusan yang jelas bahwa kedua kategori tersebut adalah sah. ${ }^{9}$ ILO sendiri pada akhirnya membagi mogok kerja menjadi mogok umum dan mogok tertentu, yakni mogok politis dan mogok simpati.

Pemogokan atau mogok kerja merupakan salah satu masalah yang dapat membuat resah dunia usaha dan mempengaruhi dalam konteks yang negatif hubungan kerja, keharmonisan dalam hubungan industrial serta keharmonisan kehidupan sosial masyarakat karena melibatkan banyak pihak yang terkait dan turut serta. Di lain pihak bagi pekerja yang melakukan pemogokan kadangkadang hanya merupakan keterpaksaan sebagai akibat buntunya pembicaraan atau tidak adanya komunikasi yang baik. Demikian adanya maka penyebab kunci

${ }^{9}$ ILO, Op. Cit., hlm. 13. 
tentang adanya mogok kerja yakni komunikasi yang tidak berjalan dengan tepat dan sempurna. ILO sendiri memberikan definisi dari mogok kerja (strike) dalam The Fifteenth International Conference of Labour Statisticians yang menyatakan demikian ${ }^{10}$ : "A strike is a temporary work stoppage effected by one or more groups of workers with a view to enforcing or resisting demands or expressing grievances, or supporting other workers in their demands or grievances."

Faktanya bahwa di negara-negara Eropa Barat pada akhir tahun 1970-an terjadi pemogokan ribuan kali yang melibatkan jutaan buruh. Pemogokan sulit untuk dihindarkan, karena bagi pekerja, mogok adalah merupakan hak fundamental yang inherent dengan hak kaum pekerja untuk berunding. Hal ini tercermin dari alasan-alasan terjadinya mogok kerja di berbagai negara. ${ }^{11} \mathrm{Hal}$ ini menunjukkan bahwa mogok kerja dapat menjadi sarana yang dapat digunakan untuk tujuan tertentu yang tidak hanya mengacu pada kepentingan pekerja murni, namun juga dapat diarahkan pada tujuan lain yang tidak berhubungan. ILO sendiri tentang mogok umum menyatakan demikian:

Mengenai mogok umum, dalam penelitian terhadap salah satu kasus tertentu, Komisi beranggapan bahwa "(suatu) aksi mogok umum selama 24 jam yang menuntut kenaikan upah minimum, dan menghormati kesepakatan bersama yang berlaku dan perubahan kebijakan ekonomi (untuk menurunkan harga dan pengangguran) adalah sah dan dalam batas bidang kegiatan organisasi-organisasi serikat buruh yang normal" (buku yang sama, ayat 495). Sama halnya dengan kasus lain, Komisi ini menyimpulkan bahwa "(suatu) aksi mogok protes umum yang menuntut dihentikannya pembunuhan ratusan pemimpin dan pengurus serikat buruh selama beberapa tahun terakhir ini merupakan kegiatan serikat buruh yang sah dan oleh karena itu, larangan atas kegiatan ini merupakan pelanggaran serius terhadap kebebasan berserikat" (buku yang sama, ayat 495$) .12$

Pemogokan-pemogokan yang terjadi di Indonesia sedikitnya disebabkan oleh berbagai faktor. Antara lain berkaitan dengan tuntutan kebebasan berserikat;

10 Dokumen The Fifteenth International Conference of Labour Statisticians, http://ec.europa.eu/eurostat/ documents/341520/4421880/Strikes/76874c4c-4074-43ed-8fcb-80069f290b23,

${ }^{11}$ Maximos Aligisakis, "Labour Dispute in Western Europe: Typology and Tendencies”, International Labour Review, 136; (Spring 1997); Geneva, 1997, hlm. 75.

12 ILO, Op. Cit., hlm. 13-14. 
tuntutan kenaikan tingkat upah; tuntutan agar diberikan Tunjangan Hari Raya; tuntutan pelaksanaan ketentuan-ketentuan hukum perburuhan (tuntutan normatif) yang berkaitan dengan pelaksanaan jaminan Sosial Tenaga Kerja, jam kerja, hak cuti (menstruasi), kontrak kerja serta syarat-syarat kerja lainnya; dan tuntutan yang berlatar belakang politik. Variasi penyebab adanya mogok kerja berkembang secara signifikan semenjak era reformasi dimulai. Keterbukaan akses atas informasi dan kesadaran akan hak, memberikan peluang terjadinya upaya memaksakan kehendak kepada pengusaha. Dampak yang ditimbulkan mogok kerja setidak-tidaknya mogok kerja dapat menyebabkan masalah-masalah seperti kerugian materiil bagi perusahaan, menghambat pertumbuhan ekonomi, menimbulkan ketidakstabilan politik dan ekonomi, hambatan investasi, dan menghambat kegiatan ekspor dan menurunnya produktivitas perusahaan. Bahwa kebebasan hak berserikat yang bersifat kapitalistik berdampak pada tingginya angka mogok kerja yang mempengaruhi hubungan industrial yang harmonis dan kesejahteraan pekerja. Untuk itu manfaat mogok kerja adalah semu karena yang tercipta adalah keadilan prosedural mogok sebagai sarana terpenuhinya tuntutan kesejahteraan pekerja, karena sebenarnya tidak pernah terjadi kesejahteraan substansial maupun keadilan substansial.

Mogok kerja digunakan sebagai alat untuk mencapai tujuan berupa tuntutan-tuntutan pekerja/buruh yang harus dipenuhi oleh pengusaha, yang terbagi atas tuntutan normatif dan tuntutan tidak normatif. Tuntutan normatif merupakan tuntutan yang didasarkan pada ketentuan-ketentuan yang terdapat dalam peraturan perundang-undangan sebagai akibat pihak pengusaha tidak memenuhi kewajiban yang diletakkan oleh peraturan perundang-undangan. Dalam hal ini Pasal 145 UU No. 13 Tahun 2003 tentang Ketenagakerjaan, mengatur bahwa tuntutan hak normatif yang sungguh-sungguh dilanggar oleh pengusaha. Penjelasan Pasal 145 menyatakan, bahwa pengusaha sungguhsungguh melanggar hak normatif, yakni pengusaha secara nyata tidak bersedia memenuhi kewajibannya sebagaimana dimaksud dan/atau ditetapkan dalam perjanjian kerja, peraturan perusahaan, perjanjian kerja bersama, atau peraturan perundang-undangan ketenagakerjaan, meskipun sudah ditetapkan dan diperintahkan oleh pejabat yang bertanggung jawab di bidang ketenagakerjaan. 
Pembayaran upah pekerja/buruh yang mogok dalam pasal ini tidak menghilangkan ketentuan pengenaan sanksi terhadap pengusaha yang melakukan pelanggaran ketentuan normatif.

Kendati sudah diakui di dalam undang-undang, sebelum melakukan mogok kerja, harus memenuhi persyaratan: (1) benar-benar sudah diadakan perundingan yang mendalam mengenai pokok-pokok perselisihan antara serikat pekerja dengan majikan; (2) benar-benar permintaan untuk berunding telah ditolak oleh pihak pengusaha; (3) telah dua kali dalam jangka waktu 2 (dua) minggu tidak berhasil mengajak pihak lain untuk berunding. ${ }^{13}$

Mogok kerja terjadi oleh karena adanya gagalnya perundingan yang mengindikasikan adanya perselisihan antara pekerja dengan pengusaha. Perselisihan tersebut kemudian diupayakan selesai dengan mengadakan perundingan, namun kemudian gagal tercapai kesepakatan. Salah satu hal yang paling mungkin diperselisihkan adalah tentang kepentingan di dalam hubungan kerja. Perselisihan-kepentingan adalah mengenai usaha mengadakan perubahan dalam syarat-syarat perburuhan yang oleh organisasi buruh dituntutkan kepada pihak majikan atau menurut perumusan di atas "pertentangan berhubung dengan tidak adanya persesuaian paham mengenai syarat-syarat kerja dan/atau keadaan perburuhan". ${ }^{14}$

Mogok kerja diawali mula-mula dengan adanya perselisihan antara pekerja dengan pengusaha di dalam suatu perusahaan. Perselisihan tersebut dapat berupa perselisihan hak, perselisihan kepentingan, perselisihan pemutusan hubungan kerja, dan perselisihan antar serikat pekerja/serikat buruh. Dari keempat obyek terjadinya perselisihan hubungan industrial tersebut, tidak ditemukan adanya perselisihan mengenai mogok kerja, akan tetapi dalam hal terjadinya perselisihan hubungan industrial ada kalanya diikuti dengan tindakan mogok kerja. Fenomena ini merupakan peristiwa hukum yang tidak mudah dihindari. Setidak-tidaknya ada 3 (tiga) penyebabnya, yaitu15:

Pertama, belum terlaksananya hubungan kemitraan di tempat kerja. Dilihat dari sisi pengusaha, hal ini merupakan akibat sikap pengusaha yang memandang

13 Abdul Khakim, Op. Cit., hlm. 176.

${ }^{14}$ Imam Soepomo, Pengantar Hukum Perburuban, Djambatan, Jakarta, hlm. 97.

15 Aloysius Uwiyono, Op. Cit., hlm. 217-218. 
buruh hanya sebagai faktor produksi serta hanya berorientasi mencari keuntungan semata. Dari segi buruhnya, belum berjalannya hubungan kemitraan di tempat kerja ini disebabkan oleh kurangnya rasa memiliki (sense of belonging) dari buruh terhadap perusahaan dimana buruh bekerja. Buruh cenderung untuk mendapatkan upah yang besar tanpa harus bekerja keras.

Kedua, kegagalan perundingan yang dilakukan oleh para pihak dalam menyelesaikan perselisihan perburuhan yang terjadi akibat ketiadaan komunikasi yang baik dan efektif. Hal ini disebabkan oleh belum adanya lembaga-lembaga yang berfungsi sebagai forum komunikasi dimana partisipasi kaum buruh dapat dilaksanakan.

Ketiga, lamanya proses penyelesaian perburuhan yang tercermin dalam mekanisme penyelesaian perselisihan perburuhan sebagaimana diatur di dalam undang-undang. Sekalipun sudah diatur secara normatif di dalam UU No. 2 Tahun 2004 tentang Penyelesaian Perselisihan Hubungan Industrial yang membatasi waktu penyelesaian sengketa selama 140 hari, masalah mekanisme yang lama prosesnya tetap ada.

Mogok kerja merupakan ultimum remidium, yakni dilakukan oleh pekerja sebagai cara terakhir untuk menekan pengusaha agar pengusaha bersedia memenuhi tuntutan pekerja. Mogok kerja memiliki kekuatan dan pengaruh, yang terletak pada sifat kolektif untuk mencapai suatu tujuan bersama (pekerja). Kolektivitas ini menjadi kunci dalam meningkatkan kelas atau posisi tawar di hadapan pengusaha. Tindakan ini dapat pula mempengaruhi produktivitas perusahaan dan menekan pihak pengusaha agar dapat mempertimbangkan keluhan ataupun tuntutan pekerja. Mogok kerja juga dapat 'mengundang' pihak lain dalam upaya menjaga situasi hubungan industrial, yakni pemerintah. Campur tangan pihak pemerintah sebagai pihak ketiga dalam membantu menyelesaikan terjadinya perselisihan hubungan industrial, dapat digunakan pekerja sebagai salah satu instrumen yang membantu pekerja dalam memperjuangkan nasib dan hak mereka. 


\section{Pengaturan Mogok Kerja di Indonesia}

Peraturan perundang-undangan tentang ketenagakerjaan telah memberikan acuan secara normatif tentang bagaimana mogok kerja dapat dilaksanakan dan tidak bertentangan dengan undang-undang. Pemogokan pada dasarnya terjadi karena adanya ketidakharmonisan hubungan antara pekerja dengan pengusaha, yang biasanya disebabkan oleh adanya tuntutan yang diajukan pekerja yang tidak ditanggapi pengusaha dengan berbagai alasan. Adanya ketidakharmonisan hubungan keduanya dan semakin banyaknya tuntutan pekerja yang tidak terpenuhi maka terjadi banyak pemogokan di Indonesia. ${ }^{16}$

UU No. 13 Tahun 2003 tentang Ketenagakerjaan mengatur pada Pasal 1 angka 23 yang bunyinya: "Mogok kerja adalah tindakan pekerja/buruh yang direncanakan dan dilaksanakan secara bersama-sama dan/atau oleh serikat pekerja/serikat buruh untuk menghentikan atau memperlambat pekerjaan." Lebih lanjut, pada Pasal 137 hingga Pasal 145 undang-undang tersebut, mengatur secara rinci perihal mogok kerja baik syarat administratif maupun syarat keabsahannya. Mogok kerja secara otentik sebagai hak dasar pekerja/buruh dan serikat pekerja/serikat buruh, yang harus dilakukan secara sah, tertib, dan damai sebagai akibat gagalnya perundingan. Maka dengan demikian, mogok kerja terjadi oleh adanya akibat gagalnya perundingan. Hal ini berarti bahwa mogok kerja seharusnya dilakukan setelah ada upaya untuk berunding, namun salah satu pihak menolak untuk berunding atau para pihak melakukan perundingan namun tidak menemukan kesepakatan atas perundingan tersebut.

Keabsahan tersebut artinya adalah mengikuti mekanisme atau prosedur yang diatur oleh UU No. 13 Tahun 2003. Konsepsi mengenai 'tertib dan damai' artinya adalah tidak mengganggu keamanan dan ketertiban umum dan tidak mengancam keselamatan jiwa dan harta benda milik perusahaan, pengusaha atau milik masyarakat. Sedangkan konsep tentang 'akibat gagal perundingan' merujuk pada adanya upaya perundingan yang telah dilakukan oleh para pihak, ternyata tidak mencapai kesepakatan (deadlock) atau perusahaan menolak untuk 
melakukan perundingan walaupun serikat pekerja atau pekerja telah meminta secara tertulis kepada pengusaha 2 kali dalam tenggang waktu 14 hari.

Pada hakikatnya, seluruh perselisihan dalam hubungan industrial harus diselesaikan melalui musyawarah untuk mufakat. Untuk hal itu, harus ditempuh jalur perundingan antara perwakilan serikat pekerja dengan pengusaha. Demi kepentingan pembuktian dan formalitas hukum, harus selalu dipastikan terdapat berita acara perundingan di atas kertas bermaterai yang ditandatangani oleh perwakilan serikat pekerja yang berunding dan pengusaha. Apabila perundingan gagal, baru pekerja diperbolehkan melaksanakan hak mogoknya. ${ }^{17}$ Syarat ini dapat disebut sebagai prosedur administratif yang dapat menentukan mogok kerja dapat memenuhi kualifikasi keabsahan secara yuridis. Gagalnya perundingan sendiri harus dapat dibuktikan dan memang telah dilaksanakan upaya-upaya penyelesaian perselisihan hubungan industrial, yakni tetap tunduk pada mekanismenya yang diatur dalam peraturan perundang-undangan yang berlaku.

Pasal 137 menyatakan bahwa "Mogok kerja merupakan hak dasar buruh, namun pelaksanaan hak dasar ini harus dilakukan secara sah, tertib, dan, damai sebagai akibat gagalnya perundingan". Penegasan pasal ini menumbuhkan makna bahwa mogok kerja sebagai hak dasar buruh baru timbul jadi ada keadaan "gagalnya perundingan". Yang menjadi pertanyaan di dini adalah fase "gagalnya perundingan". Penjelasan pasal ini menegaskan, bahwa yang dimaksud dengan gagalnya perundingan dalam pasal ini adalah tidak tercapainya kesepakatan penyelesaian perselisihan hubungan industrial yang dapat disebabkan karena pengusaha tidak mau melakukan perundingan atau perundingan mengalami jalan buntu. Penjelasan ini logis, sebab dalam kenyataannya sering terjadi buruh mempunyai keinginan atau persoalan, tetapi tidak pernah dapat merundingkannya dengan pengusaha. Jika terjadinya perundingan merupakan syarat timbulnya hak mogok kerja, maka hal ini akan merupakan kesulitan bagi buruh untuk dapat melaksanakan haknya tersebut.18 Pada Pasal 138 undangundang tersebut, pekerja/buruh dan atau serikat pekerja/ serikat buruh yang

17 Ibid.

18 Abdul Rachmad Budiono, Hukum Perburuban, Indeks, Jakarta, 2001, hlm. 211. 
berniat mengajak pekerja/buruh lain untuk mogok kerja pada saat mogok kerja berlangsung harus dilakukan dengan tidak melanggar hukum. Pekerja/buruh yang diajak mogok kerja dapat memenuhi atau menolak ajakan tersebut.

Berdasarkan Putusan Mahkamah Konstitusi Nomor 012/PUU-I/200319, Pasal 137 dan Pasal 138 UU No. 13 Tahun 2003 dinyatakan bertentangan dengan UUD 1945 dan dinyatakan tidak mempunyai kekuatan hukum mengikat. Hal ini berarti bahwa ancaman sanksi dan denda yang dikenakan, menjadi tidak memiliki kekuatan hukum yang mengikat. Pertimbangan Mahkamah Konstitusi terhadap pengaturan syarat-syarat yang ditetapkan untuk pelaksanaan hak buruh atau mogok, baik syarat bahwa mogok dilakukan secara sah dan tertib serta damai sebagai akibat gagalnya perundingan (Pasal 137), ajakan, mogok kerja berlangsung dengan tidak melanggar hukum (Pasal 138) maupun syarat-syarat administratif tentang jangka waktu pemberitahuan dan lain-lain (Pasal 140-141) tidak terdapat ketidaksesuaiannya dengan standar perubahan internasional.20 Oleh karena hal tersebut juga dikenal dalam praktek yang disetujui ILO. Sehingga standar dan norma-norma yang demikian haruslah dilihat sebagai bagian dari standar dan norma yang berlaku di Indonesia, melalui ukuran yang dikenal dalam UUD 1945. Hal itu disebabkan, hak asasi tidak dipandang sebagai sesuatu yang berlaku mutlak, sehingga sesuai dengan yang dianut dalam Pasal $28 \mathrm{~J}$ ayat (2) UUD 1945 menetapkan bahwa dalam menjalankan hak dan kebebasannya, setiap orang wajib tunduk kepada pembatasan yang ditetapkan dengan Undangundang dengan maksud semata-mata untuk menjamin pengakuan serta pengaturan atas hak dan kebebasan orang lain dan untuk memenuhi tuntutan yang adil sesuai dengan pertimbangan moral, nilai-nilai agama, dalam ketertiban umum, dalam suatu masyarakat demokratis. ${ }^{21}$

Pada penjelasan Pasal 137 UU No. 13 Tahun 2003 disebutkan, bahwa yang dimaksud dengan gagalnya perundingan yang menjadi alasan mogok kerja

${ }_{19}$ Putusan Mahkamah Konstitusi Nomor 012/PUU-I/2003, tanggal 28 Oktober 2004 tentang Hak Uji Materiil Undang-undang Nomor 13 Tahun 2003 tentang Ketenagakerjaan Terhadap Undang-undang Dasar Negara Republik Indonesia Tahun 1945 dan telah dimuat dalam Berita Negara Nomor 92 Tahun 2004 tanggal 17 Nopember 2004.

20 Tentang masalah ini, Agusmidah juga menganggap ada upaya pengekangan hak dasar universal perjuangan buruh/pekerja dan serikat pekerja/buruh dengan menetapkan prosedur administratif yang cenderung mereduksi makna mogok kerja sebagai hak dasar. Agusmidah, Dilematika Hukum Ketenagakerjaan: Tinjauan Politik Hukum, Sofmedia, Jakarta, 2011, hlm. 114.

${ }^{21}$ Lihat Salinan Putusan Mahkamah Konstitusi No. 012/PUU-I/2003, hlm. 113. 
adalah tidak tercapainya kesepakatan penyelesaian perselisihan hubungan industrial yang dapat disebabkan karena: (1) pengusaha tidak mau melakukan perundingan walaupun serikat pekerja/serikat buruh atau pekerja/buruh telah 2 (dua) kali meminta secara tertulis kepada pengusaha untuk berunding dalam tenggang waktu 14 (empatbelas) hari kerja22; atau, (2) pengusaha mau melakukan perundingan, akan tetapi- perundingan-perundingan yang dilakukan mengalami jalan buntu (deadlocked) sebagai yang dinyatakan oleh para pihak dalam risalah perundingan. Gagalnya perundingan ini menegaskan adanya keterhubungan antara Pasal 137 ini dengan mekanisme penyelesaian perselisihan hubungan industrial sebagaimana diatur dalam UU No. 2 Tahun 2004 bahwa ada suatu proses yang wajib dilaksanakan antara pihak yang berselisih.

Penyebab terjadinya mogok kerja, selain tidak adanya kehendak salah satu pihak untuk melakukan komunikasi dengan baik, juga dapat terjadi karena kebuntuan komunikasi atau tidak adanya kesepakatan (deadlocked) dalam pembicaraan sesuai dengan tuntutan (penawaran) masing-masing.

Sementara itu, tindakan mogok kerja oleh pekerja/buruh pada perusahaan yang melayani kepentingan umum dan atau perusahaan yang jenis kegiatannya membahayakan keselamatan jiwa manusia, harus diatur sedemikian rupa sehingga tidak mengganggu kepentingan umum dan atau membahayakan keselamatan orang lain. Yang dimaksud dengan perusahaan yang melayani kepentingan umum dan atau perusahaan yang jenis aktivitasnya membahayakan keselamatan jiwa manusia, misalnya rumah sakit, dinas pemadam kebakaran, penjaga pintu perlintasan kereta api, pengontrol pintu air, pengontrol arus lalu lintas udara, dan pengontrol arus lalu lintas laut. Sedangkan yang dimaksud dengan pemogokan yang diatur sedemikian rupa, yaitu pemogokan yang dilakukan oleh pekerja/buruh yang tidak sedang menjalankan tugas.

Undang-undang memberikan koridor hukum agar suatu aksi mogok kerja dapat disebut sebagai mogok kerja yang sah. Prosedur atau syarat administratif yang harus dipenuhi agar mogok kerja dikatakan sah diatur di dalam Pasal 140,

${ }^{22}$ Konsep ini dikenal dengan perundingan bipartit yakni perundingan antara pekerja/buruh atau serikat pekerja/ serikat buruh dengan pengusaha untuk menyelesaikan perselisihan hubungan industrial dalam satu perusahaan, sebagaimana diatur pada Pasal 1 angka 1 Permenakertrans No. PER. 31/MEN/XII/2008 tentang Pedoman Penyelesaian Perselisihan Hubungan Industrial Melalui Perundingan Bipartit. 
Pasal 141, dan Pasal 142, yakni: 1. pekerja atau serikat pekerja wajib memberitahukan secara tertulis kepada perusahaan/pengusaha dan instansi yang bertanggung jawab di bidang ketenagakerjaan setempat, selambat-lambatnya 7 (tujuh) hari kerja sebelum mogok kerja dijalankan; 2. surat pemberitahuan tersebut, harus memuat hal-hal: a) waktu (hari, tanggal dan jam) dimulai dan diakhiri mogok kerja, b) tempat mogok kerja, c) alasan dan sebab mengapa harus melakukan mogok kerja, d) tanda tangan ketua dan sekretaris serikat pekerja sebagai penanggung jawab mogok kerja, sedangkan bila mogok kerja akan dilakukan oleh pekerja yang tidak menjadi anggota serikat pekerja, maka pemberitahuan ditandatangani oleh perwakilan pekerja yang ditunjuk sebagai koordinator dan/atau penanggung jawab mogok kerja; 3. bagi pelaksanaan mogok kerja yang berlaku di perusahaan yang melayani kepentingan umum atau perusahaan yang jenis kegiatannya berhubungan dengan keselamatan jiwa manusia, pelaksanaan mogok kerja harus diatur sedemikian rupa sehingga tidak mengganggu kepentingan umum dan membahayakan keselamatan masyarakat; 4. instansi pemerintahan (instansi yang bertanggung jawab di bidang ketenagakerjaan setempat) dan pihak perusahaan yang menerima surat pemberitahuan mogok kerja wajib memberikan tanda terima; 5. sebelum dan selama mogok kerja berlangsung, instansi yang bertanggung jawab dibidang ketenagakerjaan wajib menyelesaikan masalah yang menyebabkan timbulnya pemogokan dengan mempertemukan dan merundingkanya dengan para pihak yang berselisih; 6. jika perundingan tersebut menghasilkan kesepakatan, maka harus dibuatkan perjanjian bersama yang ditanda-tangani oleh para pihak dan pegawai yang bertanggung jawab dibidang ketenaga kerjaan sebagai saksi; 7. dan jika dalam perundingan tersebut tidak menghasilkan kesepakatan, maka pegawai dan instansi yang bertanggung jawab dibidang ketenaga kerjaan harus menyerahkan masalah yang menyebabkan terjadinya mogok kerja kepada lembaga penyelesaian perselisihan hubungan industrial yang berwenang.

Sekalipun tata cara pelaksanaan mogok kerja diatur secara rinci di dalam undang-undang, tentang batas waktu atau lamanya waktu mogok kerja berlangsung atau diperkenankan untuk dilaksanakan, oleh UU No. 13 Tahun 2003 tidak diatur. Periode pelaksanaan mogok kerja tidak ditetapkan oleh 
undang-undang, tetapi hanya mengatur tentang persyaratan administratif saat mulai dan berakhirnya mogok kerja. Dengan tidak diaturnya jangka waktu mogok kerja yang dilangsungkan, maka dapat menyebabkan adanya peluang pelaksanaan mogok kerja tanpa mengindahkan waktu. Hal ini dapat diduga bahwa mogok kerja diajukan sebagai cara untuk memaksakan kehendak tertentu dari pekerja kepada pengusaha. Ancaman terhadap berhentinya aktivitas produksi menjadi nyata dan mempengaruhi kegiatan usaha di perusahaan.

Mogok kerja yang dilakukan tanpa memenuhi ketentuan UU Ketenagakerjaan adalah mogok kerja yang tidak sah. Dalam Pasal 3 Keputusan Menteri Tenaga Kerja dan Transmigrasi Nomor 232 Tahun 2003 tentang Akibat Hukum Mogok Kerja Yang Tidak Sah, mengatur tentang mogok kerja yang dapat dikualifikasikan sebagai mogok kerja tidak sah apabila dilakukan: i) bukan akibat gagalnya perundingan; dan/atau ii) tanpa pemberitahuan kepada pengusaha dan instansi yang bertanggung jawab di bidang ketenagakerjaan; dan/atau iii) dengan pemberitahuan kurang dari 7 (tujuh) hari sebelum pelaksanaan mogok kerja; dan/atau; iv) isi pemberitahuan tidak sesuai dengan ketentuan Pasal 140 ayat (2) huruf a, b, c, dan d UU No. 13 Tahun 2003 tentang Ketenagakerjaan.

Penggunaan hak mogok kerja secara sah, tertib, dan damai oleh buruh dan serikat buruh tidak dapat dihalang-halangi oleh siapa pun. Wujud penghalangan ini di antaranya adalah: (1) menyalahkan hukum; (2) mengintimidasi dalam bentuk apapun; atau, (3) melakukan mutasi yang merugikan. ${ }^{23}$ Selain itu, mogok kerja yang terbukti sah dan tidak melawan hukum serta dilakukan semata-mata alasan tuntutan normatif, tidak menyebabkan pengusaha bebas dari kewajiban untuk membayar upah bagi pekerja yang melaksanakan mogok kerja tersebut.

\section{Melawan Mogok Kerja}

Mogok kerja sendiri sudah dikenal dan diakomodasi dalam beberapa ketentuan perundang-undangan pada masa lalu. Melalui Pasal 161 bis dan Pasal 335 ayat (3) KUH Pidana, pemogokan di Indonesia diancam dengan sanksi pidana. Meskipun kedua ketentuan pidana tersebut di atas telah dicabut, namun dengan diundangkannya Undang-Undang No. 22 Tahun 1957, buruh-buruh yang

${ }^{23}$ Abdul Rahmad Budiono, Op. Cit., hlm. 214. 
melakukan mogok "liar" diancam sanksi pidana. Demikian pula pemogokan di perusahaan vital juga diancam sanksi pidana melalui Undang-Undang PRP No. 7 Tahun 1963. Di samping itu Undang-Undang No. 25 Tahun 1997 yang ditunda pelaksanaannya sampai dengan 1 Oktober 2002, buruh-buruh yang yang melakukan mogok tidak sesuai dengan prosedur yang ditentukan, dapat dikenakan sanksi pidana. ${ }^{24}$ Pengaturan yang demikian pada dasarnya bertentangan dengan konsep mogok kerja yang dipahami secara universal tentang hak mogok. Dalam hal pemogokan yang dilakukan oleh pekerja tidak terlepas juga peran dari serikat buruh yang melakukan pengorganisiran dan penjelasan kepada setiap pekerja mulai tentang tujuan dari aksi pemogokan yang dilakukan, bahwa pemogokan adalah hak pekerja yang diatur dan dilindungi oleh undang-undang selama itu sesuai dengan prosedur yang ditentukan oleh undang-undang itu sendiri.

Mogok kerja sendiri dilakukan pekerja sebagai langkah untuk dapat memperbaiki keadaan kerja, dan juga merupakan sebuah hak dan telah ditetapkan melalui prinsip-prinsip dasar yang mendasari hak ini, dimana diperoleh semua hak lain pada tingkat tertentu, dan yang mengakui bahwa hak mogok adalah salah satu prinsip dimana para pekerja dan serikat buruh mereka dapat mempromosikan dan membela kepentingaan ekonomi dan sosial mereka secara sah. Dan juga diakui bahwa aksi mogok merupakan hak dan bukan sekedar aksi sosial, dan juga telah menjelaskan:25 1 . bahwa hak mogok adalah hak yang dimiliki oleh para pekerja dan organisasi-organisasi mereka (serikat buruh, federasi, konfederasi serikat buruh); 2. mengurangi jumlah kategori pekerja yang dapat dicabut hak mereka atas hak ini, serta pembatasan-pembatasan hukum atas pelaksanaanya, yang tidak boleh berlebihan; 3 . menghubungkan pelaksanaan hak mogok dengan tujuan mempromosikan dan membela kepentingan ekonomi dan sosial para pekerja, namun dalam hal ini hak mogok yang dimaksud tidak berkaitan dengan kriteria mogok yang bersifat murni politis dari ruang lingkup perlindungan international yang diberikan oleh ILO; 4. menetapkan bahwa pelaksanaan hak mogok yang sah tidak boleh mengakibatkan hukuman kepada

${ }^{24}$ Aloysius Uwiyono, Op. Cit., hlm. 9 - 10.

${ }^{25}$ ILO, Op. Cit., hlm. 11. 
pekerja yang merugikan dalam hal apapun, yang termasuk diskriminasi anti serikat buruh.

Pada Pasal 141 ayat (2) UU No. 13 Tahun 2003 menyatakan, bahwa sebelum dan selama mogok kerja berlangsung, instansi yang bertanggung jawab di bidang ketenagakerjaan wajib menyelesaikan masalah yang menyebabkan timbulnya pemogokan dengan mempertemukan dan merundingkannya dengan para pihak yang berselisih. Pasal ini menyiratkan ada suatu kondisi yang harus dilewati atau suatu peristiwa yang harus dilakukan sebelum mogok kerja sungguh-sungguh dilakukan oleh para pekerja. Sehingga dengan demikian ada tiga tahapan mendasar yang dapat dijadikan acuan dalam mengupayakan tindakan melawan mogok kerja, yang tetap berdasarkan pada ketentuan peraturan perundang-undangan tentang ketenagakerjaan. Adapun tiga tahapan tersebut diantaranya: tahap pra pelaksanaan mogok kerja, tahap selama mogok kerja berlangsung, dan setelah (paska) mogok kerja berakhir.

\section{Penutupan Perusahaan (lock out) sebagai Upaya Melawan Mogok Kerja}

Tindakan penutupan perusahaan (lock out) merupakan hak dasar pengusaha untuk menolak pekerja/buruh sebagian atau seluruhnya menjalankan pekerjaan sebagai akibat gagalnya suatu perundingan. Pasal 146 UU No. 13 Tahun 2003 tentang Ketenagakerjaan mengatur bahwa pengusaha tidak dibenarkan melakukan penutupan perusahaan sebagai tindakan balasan terhadap suatu pemogokan yang menuntut hak-hak normatif, yakni kewajiban sebagaimana dimaksud dan/atau ditetapkan dalam perjanjian kerja, peraturan perusahaan, perjanjian kerja bersama, atau peraturan perundang-undangan ketenagakerjaan. Akan tetapi, lock out dan mogok kerja tidak dapat dilaksanakan secara bersamaan, atau dengan kata lain dihadap-hadapkan satu dengan yang lainnya.

Tindakan penutupan perusahaan juga tidak diperbolehkan khususnya bagi perusahaan-perusahaan yang melayani kepentingan umum serta tempat-tempat yang dapat membahayakan keselamatan jiwa manusia. Berikut ini tata cara penutupan perusahaan sebagaimana diatur pada Pasal 149 UU No. 13 Tahun 2003: 1. pengusaha wajib memberitahukan secara tertulis kepada pekerja 
dan/atau SP/SB, serta instansi yang bertanggung jawab di bidang ketenaga kerjaan setempat sekurang-kurangnya tujuh hari kerja sebelum penutupan perusahaan dilaksanakan; 2. pemberitahuan secara tertulis sekurang-kurangnya memuat: a.Waktu dimulai dan diakhiri penutupan perusahaan, b. Alasan dan sebab-sebab melakukan penutupan perusahaan, dan c. Tanda tangan pengusaha dan/atau pimpinan perusahaan yang bersangkutan; 3. pemberitahuan secara tertulis tidak diperlukan jika pekerja atau SP/SB melanggar prosedur mogok kerja; atau pekerja atau SP/SB melanggar ketentuan normatif yang ditentukan dalam perjanjian kerja, peraturan perusahaan, PKB, atau peraturan perundangundangan yang berlaku.

Persoalannya adalah kapan waktu yang tepat dapat dilaksanakan penutupan perusahaan, mengingat bahwa tindakan ini tidak diperkenankan untuk membalas mogok kerja. Penutupan perusahaan adalah hak pengusaha yang juga dilaksanakan dengan alasan gagalnya perundingan. Hal ini berarti ada kesempatan bahwa penutupan perusahaan dapat digunakan sebagai peluang melawan mogok kerja, yakni dengan memperhitungkan bahwa mogok kerja patut diduga akan segera dilaksanakan oleh pekerja. Penutupan perusahaan dengan demikian harus dilaksanakan secara hati-hati, sehingga tindakan itu dapat dilaksanakan sebelum pekerja mengajukan pemberitahuan kepada instansi perihal mogok kerja yang hendak dilangsungkan. Ini menunjukkan pula bahwa mogok kerja sendiri belum benar-benar terjadi dan dilakukan oleh pekerja, karena masih berada di tataran ide. Pada saat perundingan dianggap gagal (misal: perundingan bipartit gagal dan dicatat dalam risalah), sedangkan upaya lain sedang dalam proses, maka pengusaha dapat serta merta melakukan tindakan penutupan perusahaan yang mengacu peraturan perundang-undangan. Implikasi atau dampak dari penutupan perusahaan sendiri berupa adanya pemutusan hubungan kerja yang dapat dilakukan secara massal. Hal ini juga menjadi persoalan tersendiri yang akan dihadapi oleh baik pekerja maupun oleh pengusaha. Dengan penutupan perusahaan ini, maka keuntungan ekonomis perusahaan juga menjadi hilang karena aktivitas produksi berhenti. 


\section{Penutup}

Berdasarkan uraian-uraian sebagaimana dimuat dalam bagian sebelumnya, maka penulis dapat mengambil kesimpulan sebagai berikut: Pertama, mogok kerja yang dilakukan pekerja adalah mogok kerja yang sah apabila: a) benar-benar sudah diadakan perundingan yang mendalam mengenai pokok-pokok perselisihan antara serikat pekerja dengan majikan; b) benar-benar permintaan untuk berunding telah ditolak oleh pihak pengusaha; c) telah dua kali dalam jangka waktu 2 (dua) minggu tidak berhasil mengajak pihak lain untuk berunding. Kedua, bahwa pengusaha dapat melakukan perlawanan terhadap pelaksanaan mogok kerja dalam kerangka tiga tahapan, sebelum, selama dan sesudah mogok kerja berlangsung, tetapi harus dilaksanakan secara bertanggung jawab, yakni: mendorong penyelesaian perselisihan hubungan industrial (dibuatnya perjanjian bersama), tidak membayar upah sesuai prinsip no work no pay (sepanjang mogok kerja dilaksanakan atas dasar tuntutan non normatif), dan melakukan pemutusan hubungan kerja (sepanjang mogok kerja menyebabkan pekerja dianggap mangkir dan/atau mogok kerja dinyatakan tidak sah); atau melakukan lock out atau penutupan perusahaan oleh pengusaha, dengan tetap tunduk pada peraturan perundang-undangan yang berlaku.

\section{Daftar Pustaka}

Agusmidah, Dilematika Hukum Ketenagakerjaan: Tinjauan Politik Hukum, Sofmedia; Jakarta, 2011.

Aligisakis, Maximos. Labour Dispute in Western Europe: Typology and Tendencies, International Labour Review, 136, (Spring 1997), Geneva, 1997.

Budiono, Abdul Rachmad, Hukum Perburuhan, Jakarta, Indeks, 2001. Uwiyono, Aloysius. Hak Mogok di Indonesia, Program Pascasarjana Universitas Indonesia, Jakarta, 2001.

Ibrahim, Johnny, Teori dan Metode Penelitian Hukum Normatif, Bayumedia, Malang, 2011.

ILO, Hak Mogok, ILO, Jakarta, 2012.

Khakim, Abdul, Dasar-Dasar Hukum Ketenagakerjaan Indonesia, Citra Aditya Bakti, Jakarta, 2009. 
Konvensi ILO Nomor 87 Tahun 1948 tentang Kebebasan Berserikat dan Perlindungan Hak untuk Berorganisasi.

Konvensi ILO Nomor 98 Tahun 1949 tentang Pelaksanaan Prinsip-Prinsip Hak Berorganisasi dan Berunding Bersama

Rachmad Budiono, Abdul, Hukum Perburuhan, Indeks, Jakarta, 2001.

Soepomo, Imam, Pengantar Hukum Perburuhan, Djambatan, Jakarta.

Sumanto, Hubungan Industrial: Memahami dan Mengatasi Potensi KonflikKepentingan Pengusaha-Pekerja pada Era Modal Global, CAPS, Yogyakarta, 2014.

Sutedi, Adrian, Hukum Perburuhan, Sinar Grafika, Jakarta, 2009.

Uwiyono, Aloysius, Hak Mogok di Indonesia, Program Pascasarjana Universitas Indonesia, Jakarta, 2001.

Wijayanti, Asri, Hukum Ketenagakerjaan Pasca Reformasi, Sinar Grafika, Jakarta, 2010.

Salinan Putusan Mahkamah Konstitusi No. 012/PUU-I/2003.

Putusan Mahkamah Konstitusi Nomor 012/PUU-I/2003, tanggal 28 Oktober 2004 Tentang Hak Uji Materiil Undang-undang Nomor 13 Tahun 2003 tentang Ketenagakerjaan terhadap Undang-Undang Dasar Negara Republik Indonesia Tahun 1945 dan telah dimuat dalam Berita Negara Nomor 92 Tahun 2004 tanggal 17 Nopember 2004. 